\title{
ФІЛОСОФІЯ
}

УДК 124.5:17.022.1:101.9 Г.Лотце

DOI https://doi.org/10.32837/apfs.v0i29.951

\author{
А. В. Будз \\ ORCID ID: https://orcid.org/0000-0003-3514-9385 \\ аспірант кафедри соціальної психологї \\ Прикарпатського національного університету імені Василя Стефаника
}

\section{РОЗВИТОК АКСІОЛОГІЧНОЇ ПРОБЛЕМАТИКИ У ФІЛОСОФСЬКИХ ПОГЛЯДАХ Р. Г. ЛОТЦЕ}

Постановка проблеми. Аксіологічні питання виділяються з-поміж інших філософських питань на тій основі, що вони мають не тільки теоретичний вимір у структуруванні картини світу, але і $є$ надзвичайно важливими у практичному вимірі індивідуального та суспільного життя. Зокрема, аксіологічні питання безпосередньо пов'язані 3 екзистенційними орієнтирами життєдіяльності людини, які мають смисложиттєвий характер. Той чи інший сенс людського буття має аксіологічний вимір. Однак, незважаючи на теоретичну i практичну значущість аксіологічних питань, аксіологія як окрема наука виокремлюється у західноєвропейській філософії тільки наприкінці XIX - на початку XX століть. Зокрема, одним із засновників аксіології у іï науковому та системному аспектах вважається німецький філософ Рудольф Герман Лотце ((Rudolf Hermann Lotze (1817-1881) (далі - Лотце). У цьому аспекті важливою проблемою $є$ дослідження світоглядних та методологічних особливостей філософських поглядів Лотце, які стали основою започаткування аксіології як науки. Звідси об’єктол дослідження у цій статті є філософські погляди Лотце. Аналіз світоглядних та методологічних витоків формування аксіології у філософських поглядах Лотце дасть змогу з'ясувати логіку історико-філософського процесу та історію розвитку аксіології як науки.

Аналіз останніх досліджень і публікацій. Дослідження філософських поглядів Лотце характерне для низки дослідників. Однак вони не вивчають системно світоглядні та методологічні особливості становлення аксіологічної проблематики у поглядах Лотце. Такі дослідження його творчості здійснюються переважно у зв'язку із розвитком аксіології як науки взагалі або тими чи іншими напрямами філософії. Зокрема, М. Богданова констатуе, що «формування аксіологічної теорії як частини філософії почалося з праць Г. Лотце» $[1$, с. 22$]$ та стверджує, що «основними термінами філософії $Г$. Лотце $\epsilon$ життя та цінність...» [1, с. 22]. Однак, констатуючи ці факти, дослідниця не здійснює аналіз світоглядних засад становлення аксіології у поглядах Лотце. Я. Озе аналізує філософські погляди Лотце в контексті персоналізму, зокрема в ракурсі ідеї суб'єкта як особистості, яка є кінцевою субстанцією з унікальною свідомістю, яка є незаперечним фактом [10], однак залишає поза увагою аксіологічні ідеї Лотце. Я. Бенгтссон вивчає становлення персоналізму Лотце в аксіологічному руслі [14], але не звертає увагу на світоглядні аспекти розвитку аксіології як науки. Д. Міртов акцентує увагу на тому, що саме починаючи від Лотце термін цінність входить у науковий вжиток [9: c. LXXXVI]. Подібний факт констатує I. Гоян, який стверджує, що Лотце ввів в етику поняття «цінність» (Wert)» [3, с. 116], та О. Радугін, який зазначає пріоритет Лотце у введенні в науковий вжиток поняття «цінність» [12, с. 103]. М. Кльоцкін зауважує на гедоністичному розумінні Лотце поняття «цінність» [7, с. 54].

Із вище проаналізованих праць видно, що творчість Лотце системно не вивчається у контексті започаткування ним аксіологічної проблематики. Тому важливим науковим напрямом $\epsilon$ дослідження світоглядних та методологічних витоків формування аксіологічної проблематики у філософських поглядах Лотце, які, розвинувшись на основі кантіанства та персоналізму, стали основою для започаткування аксіології як науки.

Мета статті - проаналізувати світоглядні та методологічні особливості філософських поглядів Лотце, які стали підгрунтям для розвитку аксіологічної проблематики та водночас основою для подальшого виникнення аксіології як науки. У контексті мети дослідження основні завдання цієї статті такі: 1) проаналізувати аксіологічні аспекти персоналізму Лотце, які вплинули на виокремлення аксіологічної проблематики; 2) виявити особливості тлумачення поняття «цінність» у поглядах Лотце.

Виклад основного матеріалу. Виникнення аксіологічної проблематики у філософії має свої світоглядні та методологічні засади, які фор- 
мують логіку історико-філософського процесу та закономірність диференціації філософських наук. Диференціація аксіології зі сфери філософії засновується, на мій погляд, на певних аспектах розуміння людини, зокрема: 1) на інтерпретації людини як активного суб'єкта пізнання, яка була започаткована у гносеології трансцендентального апріоризму I. Канта на основі його «коперніканського перевороту»; 2) наданні аксіологічного статусу людині як важливому елементу буття у зв'язку із секуляризацією світогляду; 3) виникненні персоналізму, який обгрунтовує ідею унікальності та цінності людини.

1. Аксіологічний аспект персоналізму Г. Лотие. На мій погляд, кантівський трансцендентальний апріоризм є важливим гносеологічним парадигмальним конструктом, який створює засади для можливості постановки аксіологічних питань, які починають формуватися у післякантівській філософській традиції. І. Кант надає велике значення у сфері гносеології суб'єкту, якому належить пізнавальний пріоритет дійсності на основі трансцендентальних форм пізнання, на грунті яких суб’єкт конструює дійсність [6]. Відповідно, якщо суб'єкт пізнання є активний стосовно конструювання дійсності [6], то він також здатний створювати аксіологічні системи, які він пристосовує до власного буття. В такому аспекті кантівський трансцендентальний апріоризм можна вважати однією із засад секуляризації дійсності. Зокрема, така секуляризація відбувається, наприклад, в аксіологічному аспекті, бо цінності вже залежать не від трансцендентних основ, а від людини, яка конструює аксіологічні системи. Крім того, трансцендентальний апріоризм I. Канта є також підгрунтям для формування такої філософської течії, як персоналізм, який не міг би бути можливим поза межами кантівського розуміння пізнання. Оскільки відповідно до трансцендентального апріоризму I. Канта людина $є$ активною у пізнанні, то вона вже отримує самостійний статус, вона стає важливою і цінною у бутті, бо має самостійний розум, який здатний не тільки наслідувати авторитети, але також створювати нові знання.

Виходячи із трансцендентально-апріорної кантівської світоглядної установки [6], аксіологічна проблематика починає формуватися у персоналізмі Лотце, який подібно до І. Канта обгрунтовує ідею суб'єкта, який пізнає світ на основі власних пізнавальних зусиль [16]. Однак, як стверджує Я. Озе, Лотце, беручи за основу кантіанську ідею суб'єкта як активного джерела пізнання, вже трактує цього суб'єкта пізнання як особистість, як деяку кінцеву субстанцію, як свідомість, як «я», яке безпосередньо доступне для самого себе та являє собою незаперечний факт, який має найбільше значення 3 усього існуючого буття
[10, с. 127-128]. В такому аспекті не слід шукати субстанції поза «я», а оскільки душа відчуває себе суб'єктом, то вона і є субстанція [10, с. 128]. Така логіка міркувань Лотце нагадує тлумачення ляйбніцівської монади, яка також є автономною, самодостатньою та значущою [8, с. 413-429].

Саме суб’єктивізл у поглядах Лотце, який надає значущості суб'єкту внаслідок його духовної самодостатності [16], стає підгрунтям для розгортання його вчення про цінності та водночас підгрунтям для формування персоналізлу. Персоналізм своєю чергою, на мій погляд, грунтується на кантіанській парадигмі суб'єкта, оскільки персоналізм не був би можливим без визнання за суб'єктом цінності на основі його автономного володіння духом, оскільки те, що робить людину важливою, цінною, самодостатньою особистістю, - це її духовні засади.

Становлення персоналізму Лотце саме в аксіологічному руслі, тобто на основі філософії цінностей, констатує Я. Бенѓтссон: «Лотце, який отримав широке визнання та був дуже відомим філософом у Німеччині, унаслідував місце Фіхте, Гегеля та Шеллінга в Берліні, а згодом його замінив Дільтай. Він відновив ідеалістичний персоналізл не в останню чергу завдяки розвитку філософії цінностей і сенсу, яка мала істотний вплив для мислення баденських неокантіаниів, та яка також вплинула на подальші форли персоналізлу" ("Lotze, who held Fichte's, Hegel's, and Schelling's chair at Berlin and was succeeded in it by Dilthey, was widely recognized as Germany's most important philosopher. He renewed idealistic personalism, not least through his development of a philosophy of values and meaning which was of considerable consequence for the thinking of the Baden Neo-Kantians, and which would also influence later forms of personalism") [14, с. 7] (курсив мій - A.Б.). Власне, в оцінці Я. Бенгтссона персоналізм Лотце $€$ швидше наслідком його філософії цінностей. Тут слід зазначити, що поняття «цінність» вживається у поглядах Лотце в антропологічно-гносеологічному контексті [16], тобто насамперед у ракурсі цінності саме людської свідомості, яка $є$ підгрунтям для надання статусу цінності людині. Справді, якщо умовно «забрати» в людини її дух, ï̈ свідомість, то що тоді може бути критерієм значущості і цінності людини у системі буття? Без духу і без свідомості людина втрачає свою причетність насамперед до Бога, а з іншого боку, не відрізняється нічим від інших живих істот.

У своїх світоглядних засадах персоналізл Лотце пов'язаний 3 кантіанськили ученням, оскільки саме I. Кант, здійснюючи «коперніканський переворот» у теорії пізнання [6, с. 26, 28], обгрунтовує гносеологічну самодостатність людського духу на основі його апріорних форм, які є засадою функціонування чистого [6] і практичного 
[5] розуму. 3 іншого боку, філософські ідеї Лотце грунтуються на неоляйбнішіанських поглядах, у контексті яких свідомість - це найцінніше явище у бутті [10, с. 128]. Водночас слід зазначити, що Г. Ляйбніц мав неабиякий вплив на становлення філософії Х. Вольфа [13, с. 41-49], який, своєю чергою, створив методологічні засади, які стали підгрунтям для розвитку філософських учень А.Г. Баумгартена та I. Канта.

Лотце, використовуючи монадологічні ідеї Г. Ляйбніца [8], будує систему персоналізму, обгрунтовуючи ідею важливості свідомості як субстанції [16]. Оскільки ж свідомість - це субстанція, то суб'єкт, який володіє свідомістю, також отримує статус субстанції, а звідси набуває самоцінності, тим самим може класифікувати інші цінності, які супутні цій субстанції, тобто які супутні до «я» як особистості.

Саме у контексті надання вагомого значення суб’єкту Кантом [6] та Лотце [16] змінюються антропологічні уявлення про місце людини у системі буття. Внаслідок автономного володіння духом людина не просто стає суб'єктом, який здатний до пізнання на основі пригадування $[11$, с. 249$]$ чи вроджених ідей $[4$, с. 272], а стає насамперед «особистістю», яка вже є одним із найбільш значущих феноменів у бутті і займає в ньому вже автономне місце. Своєю чергою уявлення Лотце про особистість як деякий значущий феномен буття, як деяку цінність буття [16] трансформуються в аксіологічні уявлення взагалі, оскільки семантика поняття «цінність» уже поєднується в цьому разі не з буттям взагалі чи Богом, а з людиною, яка має значущість і цінність, які подібні до значущості і цінності Бога.

у цьому аспекті поняття «цінність», хоча і $є$ аксіологічним та етичним, але водночас, на мій погляд, пов'язане з онтологічною проблематикою, зокрема з поняттям «субстанція», оскільки тільки «під егідою» субстанції тим чи іншим явища буття (у тому числі суб'єкту, людині, свідомості, душі, істині) може бути наданий статус цінності. Тобто явища отримують статус цінності у зв'язку з онтологічною картиною світу, яка домінує серед філософських дисциплін, зокрема у зв'язку з обгрунтуванням ідеї субстанції. Оскільки ж людина мислиться Лотце вже як субстанція [16, с. 308], то відповідно вона отримує статус цінності.

У такому аспекті формування аксіологічної проблематики у філософії пов'язане, по-перше, з кантівським трансиендентальним апріоризмом, оскільки суб'єкт, який володіє здатністю до створення апріорних синтетичних суджень, може самостійно висловлювати судження про явища, бо всі судження мислячий суб'єкт бере сам із себе [6, с. 29]; а по-друге, з персоналізмом Г. Лотце, схильність до якого констатують Яків Озе [10, с. 135-183], Ян Бенгтссон [14]. Своєю чергою персоналізм Лотце
Ірунтувався на уявленнях про гідність та цінність суб'єктивності [16, с. $308 ; 10$, с. 123], бо суб'єкт, який набуває в персоналізмі Лотце статусу субстанції, вже самостійно може класифікувати та ідентифікувати цінності.

Очевидно, що поняття цінності (аналогічно до можливості кантіанської моралі, засадами якої є Бог, безсмертя душі та свобода [5, с. 8]) може виникнути тільки у зв' язку із наявністю «гаранта» цінності, яким у персоналізлі вже виступає людський дух, свідомість, а згодом і людина, яка вже сама стає самоцінністю, так само як самоцінністю володіє Бог. Тобто людина є цінною та унікальною істотою, бо саме вона вже визначає спосіб свого буття та здатна конструювати світ. При цьому самоцінність людини у системі буття може бути фактом тільки у зв'язку з ії найфундаментальнішими властивостями - творчою свідомістю, духом та свободою. Інакше людина у системі буття та речей не може займати ціннісної ніші та приречена на деградацію.

У такому ракурсі формування засад персоналістичного вчення у Лотце та кантіанський апріоризм стали основою для формування не тільки аксіологічної проблематики у філософії, але також для формування засад персоналізму, філософії життя, філософської антропологї, феноменологї̈, екзистениіалізму, оскільки пізнавальні апріорні здатності людини, зокрема розум у вченні Канта, стають самостійним феноменом, який здатний конструювати світ [6], а у вченні Лотце людина набуває цінності та статусу субстанції, яка тлумачиться як особистість [16]. У попередніх філософських системах питання людини вирішувалось у контексті теоцентризму та трансцендентизму, а трансцендентальний апріоризм Канта (Кант 2000) та персоналізм Лотце [16] стали основою для пошуку іманентних засад людського буття, якими є, наприклад, цінності.

2. Поняття "иінність" у поглядах Г. Лотие. 3 точки зору Д. Міртова, «вислів «цінність» (Wert), естетична, моральна, релігійна цінність... належать до тих висловів, які найбільш часто трапляються у творах Лотце, і від нього головним чином цей термін отримав право громадянства, яким користуються... в науковому вжитку» [9, с. LXXXVI]. Тобто Д. Міртов відзначає вплив Лотце на розвиток філософії цінностей і на прагматизм [9, с. XIX] та вважає, що вчення про цінність має в його філософії суттєве значення $[9$, с. LXXXVI].

У подібному аспекті I. Гоян констатує, що «історико-філософське значення Лотце полягає, зокрема, в тому, що у логіці і теорії пізнання він увів телеологічне поняття «значимість» (Geltung) як специфічної характеристики мисленнєвого змісту, а в етиці - поняття «цінність» (Wert)» [3, с. 116]. Такий факт свідчить про те, 
що навіть вводячи у науковий вжиток поняття «цінність», Лотце ще не виділяє його окремо від етики, так само як П. Лапі (Поль Лапі (Paul Lapie (1869-1927)) - французький філософ, психолог, педагог), який вводячи поняття «аксіологія», також не виділяє її зі складу етики [15, с. 371].

Водночас Лотце, вводячи поняття «значимість» (Geltung) та поняття «цінність» (Wert)» [3, с. 116], пов'язує ці категорії та вважає, що якщо для людини щось є значущим (тобто якщо воно має персональне або суспільне значення), якщо щось приносить їй задоволення, то відповідно таке явище є цінністю, оскільки чуттєвий бік людського духу визначає цінність речей і подій [16, с. 341]. Такий підхід, як вважає М. Кльоцкін, певною мірою вказує на гедоністичний аспект розуміння цінності Г. Лотце [7, с. 54]. Лотце справді наголошує на тому, що відчуття задоволення пов'язане 3 поняттям цінності $[16$, с. 308 , 341], що зближує його ідеї з праглатизлол та утилітаризлол.

Але в цілому вчення Лотце про цінності не $є$ прагматичним, як стверджує, наприклад, Д. Мiртов, який вважає, що Лотце є близьким до прагматизму щодо визнання життєвого значення істини, але водночас Лотце далекий від прагматичного релятивізму, оскільки наголошує на нормативності і всезагальності істини, тобто для Лотце істина, незважаючи на те, що вона має життєву значущість, все ж таки носить абсолютний характер [9, с. XIX]. У прагматизмі істинність і цінність мають вимір корисності та ефективності, власне утилітарно-суб’єктивістський і релятивістський зміст, а в Лотце цінність швидше має метафізичний зміст, оскільки пов'язується із людською духовністю, яка, своєю чергою, грунтується на здатності людини володіти свідомістю, яка є підгрунтям людського «я» [16]. У цьому аспекті О. Радугін відзначає, що Лотце «першим ввів у науковий вжиток поняття «цінність» для позначення гідності духовного буття людини» [12, с. 103], власне в такому сенсі поняття «цінність» вводиться у науковий вжиток Лотце у зв'язку з етикою та антропологічнил контекстом його вчення, на основі якого статус цінності надається людській свідомості та особистості.

3 точки зору самого Лотце, цінності мають системне значення для людини, бо відповідно 3 уявленнями про цінності людина формує свою життєдіяльність. Філософ стверджує: «Переконання, які формуються в нас про цінність речей і про тенденції розвитку світу, неминуче визначають собою інші сенси і значення: цінність індивідуальної особистості, рівень домагань, які, на нашу думку, ми можемо реалізувати, цілі, які ми ставимо та сподіваємось, що вони можуть бути досягнуті, обов'язки, які покладаються на нас» ("Die Meinung, welche wir von dem Werthe der
Dinge und von der Tendenz des Weltlaufs faffen, bestimmt unvermeidlich auch die andere von der Bedeutung und dem Werthe der individuellen Pers nlichkeit, von den Unspr chen, die wir erheben $\mathrm{zu}$ $\mathrm{k}$ nnen glauben, von den Zielen, die wir mit Hoffnung auf ihre Erreichung uns se en d rfen, von den Pflichten, die uns obliegen") [16, с. 310]. У такому сенсі цінність у розумінні Лотце є системним поняттям для становлення людського життя. Крім того, як зазначають дослідники, аксіологічну сферу взагалі можна вважати підгрунтям самоорганізації суспільного буття, своєрідною межею розвитку суспільства [2].

У такому сенсі поняття «цінність» може виникати тільки в антропологічно-персоналістичнолу сенсі, оскільки підгрунтям появи явища цінності як самостійного феномена природного і суспільного буття є вже не семантика поняття «Бог», а семантика поняття «людина». Хоча людина й має своє значення у контексті божественного буття (бо саме Бог створює засади для того, щоб людина була розумною, володіла свободою, була особистістю (персоною)), але саме людський дух є найціннішим із всіх творінь буття, а тому людина аксіологізується на основі власного духу, який є джерелом людського життя та співжиття. У цьому сенсі, зокрема, саме в духовності Лотце вбачає джерело моралі, стверджуючи, що «фундамент етичного життя знаходиться в нашій духовній природі...» ("die Begr ndung des ethischen Lebens in unserer geistigen Natur...“) [16, с. 338], тобто людина автономно визначає моральні цінності.

Саме тому Лотце вже розглядає поняття «ціннicmb» не в теоцентричному, а в антропологічно-етичному сенсі, пов'язуючи його $з$ поняттями людського духу, совісті та моральності [16, с. 308], які мають персоналістичний вимір. Зокрема, він вважає, що існує деяка внутрішня цінність людини, яка грунтується на «критиці совісті» "Kritik des Gewissens" [16, с. 339], «вірі в обов'язок взагалі" (“der Glaube an ein Sollen berhaupt”) [16, с. 338]. При цьому «...незнищенна ідея неухильного обов'язку супроводжує нашу діяльність та наші почуття, самооцінку нашої совісті...» ("...die unvertilgbare Idee eines verbindlichen Sollens, die unsere Th tigkeit und unsere Gef hle begleitet, die Selbstbeurtheilung des Gewissens...") [16, с. 342]. У такому розумінні мораль та аксіологія Лотце має антропологічне походження, оскільки її критерієм є людина не тільки в раціональному сенсі, але й у чуттєвому.

3 точки зору Лотце, задоволення та незадоволення - це фундаментальні причини і мотиви вчинків, при цьому він ототожнює задоволення та благо, а тому відчуття задоволення відіграє важливу роль у контексті формування морального начала та конституювання цінності, оскільки не тільки абстрактна свідомість, але й відчуття задоволення пов'язане 3 
поняттям цінності $[16$, с. 308,341$]$. Можливо, така логіка міркувань Лотце про зв'язок поняття цінності з відчуттям задоволення [16, с. 308$]$ є дискусійною і могла б бути протиставлена, приміром, логіці міркувань I. Канта про те, що підгрунтям моралі, морального закону є ідея свободи, а ідеї Бога та безсмертя душі - суть умови необхідного об'єкта волі, визначуваної цим законом $[5$, с. 8]. Але принциповим моментом у розумінні становлення поняття цінності $€$ те, що цінність у Лотце має етико-антропологічний зміст, тобто вона грунтується на внутрішній цінності людини, власне на ії духовності, яка є підгрунтям можливості етичної поведінки та на апріорних можливостях пізнання світу.

Висновки. Лотце у своїх поглядах створює світоглядні засади для розуміння людини як цінності. Людина в Лотце $€$ цінною тому, що вона сама $€$ носієм своєї внутрішньої цінності - духовності та водночас вона сама $є$ джерелом пізнання, оскільки такі форми є апріорними, а водночас об'єктивною основою пізнання.

На грунті персоналістичного розуміння цінності людини Лотце засновується світоглядне підгрунтя для виникнення поняття «цінність». Поняття «цінність» у Лотце має у своїй суті етико-антропологічне походження та грунтується на тому, що статус цінності притаманний людині внаслідок змісту її моральності та змісту їі мислення, яке саме здатне логічно обгрунтовувати ті чи інші системи, принаймні моральні. В контексті попереднього докантівського світогляду цінність мала онтологічний зміст та була пов'язана із цінністю буття або ж Бога, які є субстанційними засадами буття, а тому є цінними самі по собі. Саме тому поняття «цінність» не могло використовуватись у філософії, оскільки цінність приписувалась буттю і Богу. Тому тільки в етико-антропологічному контексті поглядів Лотце цінність отримує свій самостійний філософський статус, бо людина вже сама стає самоцінністю, а на цій основі - підгрунтям моралі, оскільки володіє голосом (критикою) совісті “Kritik des Gewissens" [16, с. 339].

$\mathrm{y}$ такому аспекті Лотце, на мій погляд, здійснює своєрідний «аксіологічний поворот» у філоcoфiї, який грунтується на його психологічних та антропологічних ідеях, зокрема, важливості людського духу та людської особистості, які стали основою для подальшого формування аксіології на основі антропологічно-персоналістичних ідей. $\mathrm{y}$ такому аспекті аксіологія Лотце та розуміння ним поняття «цінність» має перспективи подальших досліджень у зв'язку із формуванням новітніх філософських течій сучасної філософії.

\section{Jimepamypa}

1. Богданова М.М. Генеза феномена цінностей і специфіка основних аксіологічних ідей. Наукові записки
Бердянського державного педагогічного університету. Серія: Педагогічні науки. 2014. Вип. 3. С. 20-28.

2. Будз В.П. Самоорганізація суспільної дійсності в контексті ї̈ антропологічних засад та аксіологічних чинників: у 5 т. : монографія. Івано-Франківськ : Прикарпатський національний університет імені Василя Стефаника, 2017. Т. 3: Феноменологічні та аксіологічні чинники самоорганізації суспільного буття в контексті людської антропології. $501 \mathrm{c.}$

3. Гоян І.М. Історико-філософська рефлексія психологізму: на перетині філософії і психології : монографія. Івано-Франківськ : Симфонія форте, 2011. 360 с.

4. Декарт Р. Рассуждение о методе, чтобы верно направлять свой разум и отыскивать истину в науках / пер. с фр. Г. Слюсарева. Рене Декарт. Сочинения: в $2 \mathrm{~m}$. Москва: Мысль, 1989. Т. 1. С. 250-296.

5. Кант I. Критика практичного розуму / пер. 3 нім., приміт. та післям. І. Бурковського; наук. ред. А. Єрмоленко. Київ : Юніверс, 2004. 240 с.

6. Кант I. Критика чистого розуму / пер. 3 нім., приміт. та післям. І. Бурковського. Київ : Юніверс, $2000.504 \mathrm{c}$.

7. Клёцкин М.В. Онтологические основания ценностной детерминации научного познания : монография. Москва : Библио-Глобус, 2018. 290 с.

8. Лейбниц Г.-В. Монадология / пер. с фр. Е.Н. Боброва. Г.-В. Лейбнии. Собрание сочинений: $84 \mathrm{~m}$. Москва : Мысль, 1982. Т. 1. С. 413-429.

9. Миртов Д.П. Учение Лотце о духе человеческом и Духе Абсолютном. Санкт-Петербург : Типогр. В.Д. Смирнова, 1914. CXLVII с., 518 с. URL: http:// books.e-heritage.ru/book/10072944 (дата звернення: 12.03.2021).

10. Озе Я.В. Персонализм и проективизм в метафизике Лотце. Юрьев : Типогр. К. Матисена, 1896. 476 с. URL: http://books.e-heritage.ru/book/10077575 (дата звернення: 20.03.2021).

11. Платон. Федон. Платон. Діалоги / ред. та пер. з давньогрец. Й. Кобіва. 2-ге вид. Київ : Основи, 1999. С. 234-292.

12. Радугин А.А., Перевозчикова Л.С. Проблема онтологического статуса ценностей в истории аксиологии. Научные ведомости. 2015. № 8(205). С. 102-110.

13. Arnsperger W. Christian Wolff's Verhältnis zu Leibniz. Weimar : Verlag von Emil Felber, 1897. 72 p. URL: https://archive.org/details/bub_gb_b9ou AAAAYAAJ/page/n3/mode/2up (дата звернення: 28.03.2021).

14. Bengtsson J.O. The Worldview of Persnalisn: Origins and Early Development. New York : Oxford University Press, 2006. $310 \mathrm{p}$.

15. Lapie P. Logique de la volonté. Paris : Felix Alcan, 1902. 400 p. URL: https://gallica.bnf.fr/ark:/12148/ bpt6k743455/f1.item.r=Lapie\% 20P (дата звернення: 16.03.2021).

16. Lotze H. Der Mensch. Der Geist. Der Welt Lauf. Mikrokosmus. Ideen zur Naturgeschichte und Geschichte der Menschheit. Versuch einer Anthropologie: in 2 Bänd. Vierte Aulage. Leipzig : Verlag von S. Hirzel, 1885. Zweiter Band. 466 s. URL: https://www.europeana.eu/en/item/9200143/ BibliographicResource_2000069321369?1\%5Br\%5D=12\&l $\% 5 \mathrm{Bt} \% 5 \mathrm{D}=33$ (дата звернення: 20.02.2021). 


\section{Анотація}

Будз А. В. Розвиток аксіологічної проблематики у філософських поглядах Р. Г. Лотце. - Стаття.

У статті розглянуто особливості формування аксіологічної проблематики у філософських поглядах Лотце. Висунуто думку про те, що він здійснює своєрідний «аксіологічний поворот» у філософії. Зокрема, проаналізовано світоглядні та методологічні особливості філософських поглядів Лотце, які стали підгрунтям для розвитку аксіологічної проблематики та основою для подальшого виникнення аксіології як науки. Такий аналіз філософських поглядів Лотце стосовно розробки ним засад аксіології здійснено у контексті кантіанства та персоналізму. У статті обгрунтовано, що аксіологічні ідеї Лотце засновуються на таких світоглядних засадах, як кантіанський трансцендентальний апріоризм та персоналізм. Досліджено аксіологічні аспекти персоналізму Лотце, які вплинули на виокремлення аксіологічної проблематики у його поглядах. Виявлено особливості тлумачення поняття «цінність» у поглядах Лотце. У статті показано, що диференціація аксіології зі сфери філософії засновується на світоглядних аспектах розуміння людини та її значущості у бутті. Зокрема, встановлено, що виокремлення аксіологічних питань у філософії Лотце відбувається на основі інтерпретаціі ним людини як активного суб'єкта пізнання, яка започаткована у гносеології трансцендентального апріоризму I. Канта. Суб’єктивізм у поглядах Лотце, який полягає у наданні значущості суб'єкту як явищу буття внаслідок його духовної самодостатності є підгрунтям для розгортання у його філософських поглядах вчення про цінності. Окреслено, що надання людині аксіологічного статусу як важливому елементу буття та обгрунтування ідеї унікальності та цінності людини у персоналізмі Лотце на основі значущості їі духу стали підгрунтям для виокремлення у його поглядах аксіологічної проблематики. Лотце трактує суб'єкта пізнання як особистість, як «я», як духовну субстанцію, як свідомість, яка є незаперечним фактом, який має найбільше значення в бутті. У статті показано, що поняття «цінність» у філософських поглядах Лотце вживається в антропологічно-гносеологічному контексті, тобто у ракурсі цінності саме людської свідомості, людського духу, які вже стають підгрунтям для надання статусу цінності людині. Доведено, що семантика поняття «цінність» у поглядах Лотце розвивається не на основі цінності буття чи Бога, а на основі цінності людини, яка має значущість і цінність внаслідок значущості і цінності їі свідомості, власне їі духу. Поняття «цінність» у поглядах Лотце має етико-антропологічний зміст, оскільки Ірунтується на внутрішній цінності людини, на цінності її духовності.

Ключові слова: Р.Г. Лотце, персоналізм, суб'єктивізм, аксіологія, цінність, цінність людини, особистість.

\section{Summary}

Budz A. V. Development of axiological issues in the philosophical views of $R$. H. Lotze. - Article.

The peculiarities of the formation of axiological problematics in the philosophical views of Lotze are examined in the article. It is established that he makes a peculiar "axiological turn" in philosophy. In particular, the worldview and methodological peculiarities of the philosophical views of Lotze that became the grounds for the development of axiological problematics and the basis for further emergence of axiology as science are analyzed. Such analysis of Lotze's philosophical views regarding the development of the grounds of axiology is made in the context of Kantianism and personalism. In the article, it is substantiated that Lotze's axiological ideas are based on such worldview grounds as Kantian transcendental apriorism and personalism. Investigated are the axiological aspects of Lotze's personalism that affected the separation of axiological problematics in his views. The peculiarities of interpretation of the concept of "value" in Lotze's views are detected. In the article, it is showed that the differentiation of axiology from the philosophy sphere is based on worldview aspects of the understanding of human and his/her significance in existence. In particular, it is established that such differentiation happens based on his interpretation of human as an active subject of cognition, which was introduced in gnoseology of transcendental apriorism of I. Kant. Subjectivism in Lotze's views, which lies in granting the significance to the subject as a phenomenon of existence due to its spiritual self-sufficiency, is the basis for the deployment in his philosophical views the doctrine about values. It is outlined that the granting of axiological status to human as an important factor of existence and the substantiation of the idea of uniqueness and value of human in Lotze's personalism based on the significance of his/her spirit became the grounds for the separation of axiological problematics in his views. Lotze interprets the subject of cognition as a personality, as "self", as a spiritual substance, as consciousness that is an undeniable fact, who has the biggest significance in existence. In the article, it is shown that the concept of "value" in Lotze's philosophical views is used in an anthropological-gnoseological context, i.e., from the perspective of values of human consciousness, the human spirit that becomes the basis for granting the status of value to human. It is proved that the semantics of the concept of "value" in Lotze's views is developed not based on the value of existence or God, but based on the value of human, who has significance and value due to the significance and value of his/her consciousness, spirit. The concept of "value" in Lotze's views has an anthropological meaning since it is based on the internal value of human and his/her spirituality.

Key words: R.H. Lotze, personalism, subjectivism, axiology, value, value of human, personality. 